Pakistan Journal of Education

Vol.37, No.1, 2020, 95-112

\title{
Predicting the Role of Study Habits in Academic Achievement: A Study of University Students in Punjab
}

\author{
Tehsin Ehsan* \\ Naveed Sultana**
}

\begin{abstract}
The present study was designed to predict the role of study habits in academic achievement and to identify the study patterns and environment for studying of high, average and low achievers at University level. This was a survey study based on data from 1334 student from government universities of Punjab include same departments. Students were chosen proportionately, according to the existed total number of the students in the department. Data was collected through a self-developed questionnaire. Semester GPAs were taken to divide students' in. high, average and low achievers. Reliability coefficient of study habits questionnaire was .866. The findings revealed that all university students like to study silently but percentage of high achievers is comparative elevated in this pattern. As far as environment for studying is concerned it was found that preferred environment of low and high students was studying in bedroom and study in T.V lounge is commonly used by low and average students. Result showed that the study habits play positive role in the improvement of academic results in university scholars in Punjab.
\end{abstract}

Keywords: study habits, academic achievement.

\footnotetext{
* Ph.D Scholar, Department of Teacher Education, Allama Iqbal Open University, Islamabad, Pakistan

** Chairperson, Department of Education, Allama Iqbal Open University, Islamabad, Pakistan
} 


\section{Introduction}

One cannot deny the importance of teaching in students' success. As teaching includes involvement, prepare students to listen and activate them (Tait, 2016). But there are number of factors that are also related to learning of students. These factors include learning style and practices used by the students. These factors also affect the learning and performance of students. Most of the teachers are in the view that learning is directly linked with studying behavior of the students towards their learning. Learning in academics is described differently. Effective learning of students largely depends upon their regular practices and habitual ways of studying. It is related to students' interest and motivation. According to Ehsan (2017) learning is related to the ability of learner to devote their time for studying, prepare a schedule, focus the concentration, mental preparation and note taking, organized and shared learning.

All human beings do their work according to their own tempo and capabilities. They set their time in relation to their desires and requirements. They all are different in their habits and schedules and these habits and schedules are connected with their performance. Keeping in view, they set their time for studying.

Effective and ineffective study habits channelize their achievement in their academics. In a research study conducted by Odiri (2015) established that the learners who had efficient study habits gain high position as compare to those learners who secure low grade. Jones, Slate \& Kyle (1992) expressed that students of different disciplines frequently experience troubles in their studies and their attitudes towards learning and may use inappropriate approaches to learning. These include their studying approaches, their attitude towards learning and management of time.

In general, study habits include managing the resources which is concerned with management of time for the completion of a scholarly activity. Basically, these are regular routine and adept patterns of studying that need no alert and conscious efforts (Flippo \& Caverly, 2000). These practiced efforts are an important element of study habit and this central part of habit leads towards academic commitment.

\section{Background of the Research}

Students are independent at higher education level. They map their activities according to their needs and requirements. Studying patterns and habits developed at very early age. University students need to adjust 
their studying habits, to meet the requirements of higher studies. The students with already developed good habits for studying can easily adjust for studying. Efficient study habits are fundamental to learning. It is closely related to academic performance. So, it is crucial to highlight this important phenomenon. Things that are not related to academics and learning may also improve study habits of students these include; increased motivation, organization of time, and avoid procrastination.

With the arrival of new technology and change in our life patterns, study habits of student are ignored. They used to spend more time on computer and internet related activities. It is dire need to investigate their study habits in current scenario. Ineffective study habits could negatively overshadow the benefits of high-quality learning environment and intellectual capabilities. Whereas, good study habits can improve deficiency and weakness in academics. This may have favorable effects on academic achievement. This study may lead the scholars to identify their potential practices and habits for studying to improve their learning. This study is effective for teachers to sensitize this issue in their classes and make the students aware and facilitate them to inculcate good habits for studying.

Current research is designed to predict the role of study habits in academic achievement. The knowledge regarding the importance of efficient habits leads to build up healthy study habits that result in healthy learning. The current research explored healthy study habits which results in high academic achievement. The role of efficient and inefficient study habits in academic achievement direct the investigator to offer empirically based recommendations to develop efficient study habits which produce high academic learning.

\section{Literature Review}

Study is an organized implementation of intellectual abilities to a situation. Habit is an action that is carried out without aware thinking or attention. In other words habits are regular practices to perform a task. It initiates building up with conscious efforts but with by practicing it happens automatically (Goel, 2014). Study habits are the habitual practices and capabilities of an individual to get knowledge (Kumar, 2015).

Lexicoby Oxford Dictionary (2019) defined study as

"The devotion of time and attention to acquire information or knowledge especially from books or in other words it's the pursuit of academic knowledge by a detailed investigation of a subject or situation" 
Since long studying is the prime source through that learning outside the class may occur. Independent study is developed in students through home task. Under the supervision of teacher, students are given projects and they reorganize related information by their guided feedback. Mostly, students depend on library resources to ascertain updated knowledge or they get benefit from updated technological resources. They have to work independently. In this process their study habits, attitude and motivation for learning may play vital role in their success and on the other hand in their failure. For personality building and in education habits are crucial. Individuals' habits put aside exhaustion and fatigue as through good habit an individual leads his/her life pleasant, efficient and successful (Goel, 2014).

Particularly, study habits are linked with extraneous variables that facilitate the process of learning; it also helps to maintain concentration during studying period, analyzing and detailed description of the material and creating an environment where learning may occur (Cerna \& Pavliushchenko, 2015).

Study habits include following a schedule with commitment and continuously devote a time to a learning task. In the absence of these, one cannot improve and elevate in life (Rabia, Mubarak, Tallat, \& Nasir, 2017). Habits related to studying acquaint an individual that to what extent he will gain and to what extent he wishes to move forward, and at the end his earning is also depends on this. One can predict all these through one's study habits. Study habits are constructive time used in integrating into one's life. As habits plays important role in saving time and efforts in life and through these success and confidence can be achieved that is priceless (Holt, 2007).

Study habits include all related actions during the learning process. The purpose of these habits is to bring out and direct learner's cognitive processes. Patel (2016) expressed that habits are accurate index of a person. He explained that study habits are the activities of a person which are related to learning. In learning process, study habits are students' routine approaches of practicing and application of competencies to learn are regarded as study habits. The specific mode of behavior applied by a learner for a task is considered as their study habits. Their personality is depicted by their study habits. Learning quality of an individual is characterized by his study habits.

Nonis \& Hudson (2010) are in a view that all learning strategies don not give same results as far as academic performance is concerned however, it is predictable that if a student posses good habits may perform better. 
The same idea was elaborated by Bajwa, Gujjar, Shaheen, \& Ramzan, (2011) that study habit is a basic competency of an individual and it can be learnt. Basically, it is students' tendency towards study in an available learning situation. Learners cannot get fruitful outcomes unless he/she bear good study habits. There are differences exist in learning and study habits are one of the reason behind.

Peer or group learning is commonly helpful. It involves knowledge sharing, thoughts and experience among individuals. It ranged from independent to interdependent learning. Learning accure when students explain their views to their group members and in the same way they can learn from their peers (Boud, 2001). According to Macpherson (2015) through cooperative learning group activities students' critical thinking can be enhanced.

Many researchers tried to discover the effects of time spend for studying on academic achievement. Blazer (2008) found those students who need more time, can get benefit from extra time during their school. Sarath, Nonis \& Hudson (2006) pointed that time spend is not the only key but its effective use is also estimated. Stinebrickner \& Stinebrickner (2004) described that the atmosphere where study is carried out also have an effect on the achievement.

Ebele \& Olofu (2017) mentioned that one of the largely influenced factors on students' learning and success is learners' study habits. Fielden advocate in 2004 that "good study habits help the student in critical reflection in skills outcomes such as selecting, analyzing, critiquing, and synthesizing". Ebele \& Olofu (2017) enlightened that the way a student plan his/her studies generally determine his success in academics. The way he/she is prepared for learning task and the way different approaches he/she plan and apply deliberately, influence and determine their position in academic success. The same idea was explained by Mark \&Howard (2009) that lack of efficient study habits is widespread hurdle in students' achievements. They also promote that the development of effective study habits and high-quality regulation, the students are forced to give their best in all of their scholarly tasks.

Ebele, \& Olofu, (2017) quoted Grace (2013) that the process to learn is slight mysterious but researches demonstrate that highly efficient process for studying include extremely constructive activities for a specific period. Put it differently, for effective learning a person is required to study, illustrate, make comparison, learn, and evaluated for a specific time. Studying attitude has huge contribution in academic success and in adopting effective pattern or modes of studying. Victorious scholars take up positive approach for studying; they do not waste their time as their vision is clear about their learning. The learning 
situation also facilitate students in this process as pleasant learning experience leads towards positive learner's attitude and motivation, and unpleasant learning experiences leads them to avoid it.

In the opinion of $\mathrm{Yu}$ (2011) the students must be capable of understanding course material, absorbing, and reflecting on it and capable of communicating the acquired knowledge orally or in written form, if they want to be successful academically. The basic thing is their ability to adopt good study habits. In the opinion of some students hours/time for studying is of great worth.

Getting the knowledge of which habits are effective for someone and which are not effective, at the same time identifying study approaches/patterns and relate them with associated grades, then actively generating a study schedule and adopt the plan according to tested methods, is the most influential device (Ashish, 2013 cited in Ebele, \& Olofu, 2017).

Leyden (2015) discovered, the basic goal of effective study habits is to enhance students learning. He further explained that good study habits includes following a study plan, taking short breaks while studying, preparing notes, regularly investigate questions and examine then on regular basis, learning from mistakes and implement them in actual life.

$\mathrm{Hu} \& \mathrm{Du}$ (2012) discussed

"Self directed study refers to a way that learner in learning activities have acquired subject consciousness and self awareness, and constantly stimulate study passion or enthusiasm, giving full play to the imitative in the learning process. Self directed study includes several parts: the study habits, interest, method and ability, which is different from what we called self study. Self study is just a component in it".

There are certain study habits which are considered as merely actions. i.e. first recognizing constructive time for studying, plan goals for study sessions. Prepare difficult subject first, select a peaceful place for studying, avoid distractions and reviewing handouts before and after class instruction (Leyden, 2015). Willingham (2010) mentioned "study in a quiet place, with as few distractions as possible. Do not listen to music or TV... It is virtually impossible to do two things at once if one of them is studying". He was also in favor that students should not encouraged multitasking when they are engaged some important assignment. Patel (1976) considered, home environment, habits of studying and taking notes, setting up the work, arrangement of subjects, concentration level, preparing for exams, usual attitudes and habits, and institutional environment, as study habits. 


\section{Objectives of the Study}

The current research was intended to:

- Identify the study patterns of high, average and low achievers of the university students;

- Identify the environment for studying of high, average and low achievers of university students;

- anticipate the function of study habits in the academic achievement of university students in Punjab.

\section{Research Questions}

1. What are the study patterns of high average and low achievers at university level?

2. In which environment high, average and low achievers at university level used to study?

\section{Hypothesis}

$\mathbf{H o}^{1}$ : Study habits do not play any function in academic achievement of university students in Punjab.

\section{Methodology}

In current research, quantitative research approach was used as it is a survey study. Survey research design is used when the researcher want to collect information regarding attitudes, opinions, behaviors, characteristics or interest of the population (Creswell, 2012). Survey was performed to collect data from 1334 students.

\section{Sample}

This study was conducted in the Public sector Universities located in Punjab. Seven universities (Public sector) were targeted on the basis of having five common departments. These common departments were Computer Sciences, Education, Economics, Environmental Sciences, and Management sciences. The population consisted of 3507 Masters level university students. The selected sample for current study was 1334 students which were selected from these public sector universities of Punjab. Students from each department were selected proportionately, according to the existed total number of the students in the departments. 


\section{Instrumentation}

To determine the study habits, a questionnaire consisted of 35 items was developed. An eleven member expert team validated the Study Habit Questionnaire (SHQ). Taking into account the valuable comments and suggestions of the experts, format and language of the questionnaire was upgraded.

The questionnaire was pilot tested before final administration to the actual sample. To perform pilot testing 328 students were selected as a sample. To measure the internal consistency of the instrument, Cronbach Alpha reliability was calculated. The scores showed that the questionnaire is reliable $\alpha=.866$.

The sample of students was drawn from five different departments and their academic achievement cannot be measured through one standardized test. So, the academic achievement was calculated by their respective departments. In present research, students' academic success is concerned with their habits of studying. So, to meet this purpose their semester GPA's were taken. Their GPA scores showed that they are high, average and low in academics.

The three categories are selected based on following criteria:

1. High Achievers: GPA $>3.5$

2. Average Achievers: GPA $\geq 3.00$ to 3.5

3. Low Achievers: $\leq 3.00$

\section{Results}

Table 1

Frequencies and percentages of Pattern of study on the basis of High, Average and Low Achievers

\begin{tabular}{|c|c|c|c|c|c|c|c|c|c|c|}
\hline \multirow[t]{2}{*}{ Achievers } & \multicolumn{2}{|c|}{$\begin{array}{l}\text { Studying } \\
\text { aloud }\end{array}$} & \multicolumn{2}{|c|}{$\begin{array}{l}\text { Walk while } \\
\text { studying }\end{array}$} & \multicolumn{2}{|c|}{$\begin{array}{l}\text { Studying } \\
\text { Silently }\end{array}$} & \multicolumn{2}{|c|}{$\begin{array}{c}\text { Music/ } \\
\text { T.V while } \\
\text { studying }\end{array}$} & \multicolumn{2}{|c|}{$\begin{array}{l}\text { Group } \\
\text { Study }\end{array}$} \\
\hline & $\mathrm{F}$ & $\%$ & $\mathrm{~F}$ & $\%$ & F & $\%$ & $\mathrm{~F}$ & $\%$ & $\mathrm{~F}$ & $\%$ \\
\hline High & 103 & 13.3 & 117 & 15.1 & 343 & 44.1 & 35 & $\begin{array}{l}4 . \\
5\end{array}$ & 179 & 23 \\
\hline Average & 267 & 21 & 201 & 15.8 & 406 & 32 & 59 & $\begin{array}{l}4 . \\
6\end{array}$ & 336 & 26.5 \\
\hline Low & 116 & 17.8 & 93 & 14.3 & 243 & 37.4 & 44 & $\begin{array}{l}6 . \\
8\end{array}$ & 154 & 23.7 \\
\hline
\end{tabular}


Table 1 shows percentages and frequencies of three groups i.e. high, average and low achievers, on diverse patterns of study. The table showed that in studying aloud pattern; the high achievers' proportion was 13.3 , average students' was $21 \%$ and low achievers was $17.8 \%$ respectively. It is evident that studying aloud is most common in average students. The other pattern walk while studying, $15.1 \%$ high achievers, $15.8 \%$ average students and $14.3 \%$ low achievers apply this category. In the pattern of study silently, the percentage of high, average and low achievers is $44.1 \%, 32 \%$ and $37.4 \%$ respectively. In the forth pattern, study while listening music or watching T.V. the acquired percentage is $4.5 \%$ high, $4.6 \%$ average and $6.8 \%$ in low achievers, whereas $23 \%$ high, $26.5 \%$ average achievers and $23.7 \%$ low achievers prefer to study in group.

Table 2

Frequencies and percentages of Environment of the study on the basis of High, Average and Low Achievers

\begin{tabular}{lcccccccc}
\hline & \multicolumn{2}{c}{ Bedroom/study room } & \multicolumn{2}{c}{ T.V. Lounge } & Study in Library/Lab & \multicolumn{2}{c}{$\begin{array}{c}\text { Campus } \\
\text { Lawn/ Café }\end{array}$} \\
& & & & & & & & \\
Achievers & F & $\%$ & F & $\%$ & F & $\%$ & F & $\%$ \\
\hline High & 397 & 60.6 & 43 & 6.6 & 105 & 16 & 110 & 16.8 \\
Average & 476 & 49.2 & 109 & 11.3 & 157 & 16.2 & 226 & 23.3 \\
Low & 374 & 60.5 & 53 & 8.6 & 80 & 12.9 & 111 & 18 \\
\hline
\end{tabular}

The above table provides the results of students' environment of the study on the basis of high average and low achievers. This table shows sufficient facts that $60.6 \%$ high achievers, 49.2 average and $60.5 \%$ low achievers used to study in their bed rooms or study rooms (calm place). Whereas $6.6 \%$ high achievers, $11.3 \%$ of average and $8.6 \%$ low achievers study at noisy places. In case of study in library or lab, $16 \%$ high achievers, $16.2 \%$ average achievers and $12.9 \%$ low achievers use this method. The table showed that 16.8 high, $23.3 \%$ average, and $18 \%$ low achievers study at campus lawn or cafe.

Table 3

Regression Analysis of Study habits and Academic Achievement

\begin{tabular}{ccccccccccc}
\hline Model & $\mathrm{R}$ & $\begin{array}{c}\mathrm{R} \\
\text { Square }\end{array}$ & $\begin{array}{c}\text { Adjusted } \\
\text { R Square }\end{array}$ & $\begin{array}{c}\text { SE of } \\
\text { the } \\
\text { Estimate }\end{array}$ & $\mathrm{F}$ & $\mathrm{B}$ & $\begin{array}{c}\text { Coefficient } \\
\text { Beta }\end{array}$ & $\mathrm{T}$ & $\mathrm{p}$ \\
\hline 1 & .510 & .260 & .259 & .36570 & 467.87 & .013 & .510 & 21.630 & .000 \\
\hline
\end{tabular}

Predictors (constant), Study Habits Score

Dependent variable: Academic Achievement score 
The prediction regarding the role of study habits in academic achievement of university students, simple regression was calculated. It is evident from table 3 that correlation is $\mathrm{R}=.510$ and coefficient of determination is 0.260 ; which means due to s study habits of student $26 \%$ of the variation in the academic achievement is found. $\mathrm{R}$ is significant as $F(1332)=467.87$ is significant at 0.000 level. It is predicted through regression equation that study habits scores significantly calculate academic achievement scores. The coefficient of 0.260 demonstrates that study habit is the cause of improvement of academic achievement.

\section{Findings}

Following findings were sought out on the basis of results:

1. The first objective was to identify the study patterns of high, average and low achievers of university students in Punjab. Study patterns of high, average and low achievers are different. Study aloud is most common habit of average achievers and it is less common in high and low achievers. No difference was found in walk while studying of these three groups as it is less desired pattern in these groups. Study silently was the preferred study pattern of all students but the percentage of high achievers is high in study silently when we make comparison with other groups. Study while watching T.V or while listening to music is less common in students. However, group study is most famous pattern in average students.

2. There were differences found on the basis of preferred environment for study. It was found that calm places like bedroom or study room are preferred all three groups but when we compare them with each other high and low achievers mostly study in bedroom or in study room. It is also seen that T.V lounge is also most common place for study, in average and low achievers. High and average students prefer to use library for studying and commonly, average group enjoyed studying in campus lawn or cafe.

3. The third objective, role of study habits in the academic achievement of university students proved that study habits were positively correlated with academic achievement.

\section{Discussion}

The current study discovered the students' study habits with reference to their academic achievement. 
In current research showed studying silently seemed most popular study pattern of but all three categories of university students but it seemed most common in average achievers. There is no visible differences in study pattern i.e. walk while studying of high average and low achievers of university students. According to Hong \& Milgram (2000) many students prefer to remain on one place to learn for longer time, while some other students' like to walk or move around the home or room while they are studying. Study while watching T.V or while listening to music seemed less common in students but low achievers prefer to study while listening to music or watching T.V. According to Landau (2010), quoted in Elangovan (2014) a study students showed poor performance who study while listening to music whereas their performance was outstanding in the quiet environment. It was recommended by the researchers that "it might be better to study for an exam in quiet, or listen to music beforehand". A research revealed "the degree of conscious engagement with the activity is higher than the degree of conscious engagement with the music". The researcher mentioned that when students use music during studying that leads towards high order thinking as their concentration is not music related (Rinsema, 2016). The current research showed that studying in groups was the most desired pattern of average students. Researches revealed that students' academic achievement may be improved through informal and formal groups and studying in a group direct towards achievement. These studies also revealed that studying in groups shows the way towards good student grades and developcritical ideas (Hall, Ramsay \& Raven, 2004; \& Bertucci, Conte, Johnson, \& Johnson 2010).

The previous researches emphasized that the place where an individual study is also a major contribute towards his success. The present study revealed that a small percentage of students used to study in T.V lounge. The place for studying is suitable for learning and presented in a friendly way, subsequently it is crucial to meet the need and expectations of learners (Walton, 2006). It is evident through a research by Harrop \& Turpin (2013) that some students prefer to study in specific environment or on a specific seat. Whereas, many students used to study anywhere which meets basic requirements for their study and they do not plan their environment for studying. Our environment trained us to behave in a specific way, consequently, the ideal environment for studying for learners is that encourages and supports the task. Selecting a calm place for study makes the study environment satisfying and encouraging. Whereas, to stay away from distraction set study area away from television or do not arrange study space in a high traffic (Kuther, 2015; Cerna, \& Pavliushchenko, 2015). 
Informal learning places are preferred by the students to do their independent or individual tasks. They perform these self directed tasks within library premises (Harrop \& Turpin, 2013). The undertaken study showed that the percentage of students who study in library at campus is few. High and low achievers prefer to study in bedroom or in a specific study room. In comparison with high achievers, the average and low achievers group accustomed of studying in the T.V lounge. Researches related to study habits discovered that majority of students in the habit of studying in calm places or in separate rooms (Igun \& Adogbeji, 2007) but comparatively, studying while listening to radio and/or television is less common (Helsel \& Miles,1985), preferred to study in group at learning centre and to carry out independent study at home (Harrop \& Turpin, 2013).

It is predicted through this study that there is positive correlation found between study habits and academic achievement and effective study habits makes about $26 \%$ difference in the academic achievement. Many studies showed study habits as an important factor of academic achievement and demonstrated a positive association between these variables (Nonis \& Hudson, 2010; Fereidouni Moghadam \& Cheraghian, 2009; \& Cerna \& Pavliushchenko, 2015). Some studies also predict low negative correlation between these variables which shows significant low correlation between study habits and academic achievement (GarnerO'Neale \& Harrison, 2013; Budhiraja \& Sareen, 2013). The findings of current research also opposed with the research of Lawrence (2014) that demonstrate no relationship between these two variables.

\section{Conclusions}

In the light of finding, it was concluded that;

1. University students use all these habits i.e. studying silently study in groups, studying aloud, walk while studying, and studying while listening to music but most commonly all three groups (high, average and low achievers) prefer studying silently. Whereas studying aloud and group study frequently used by average and low achievers and less common in high achievers.

2. High and low achievers like to study in their bedrooms or study rooms while average students preferred to sit in T.V. lounge, library and on campus lawn for studying .

3. It was established that academic achievement is the result of effective and ineffective study habits of students. 


\section{Recommendations}

1. It was recommended that study silently and group study may be encouraged by teacher supported thinking and intervention as study silently promote creative thinking; enhance attentiveness and insight whereas group/peer learning promote shared learning and bridging the gap.

2. Educational institutions (schools, colleges, and universities) may provide institutionalize students' mentoring services which may direct learners behavior regarding studying and their way of thinking and inculcate a variety of study habits. By doing this there are a number of topics related to motivation, tutorial, counseling sessions, how to take notes and many more students concerns may be satisfied. 


\section{References}

Bajwa, N., Gujjar, A. A., Shaheen, G., \& Ramzan, M. (2011). A comparative study of the study habits of the students from formal and non-formal systems of education in Pakistan. International Journal of Business and Social Science. 2(14), 175-186.

Boud, D. (2001). Peer learning in higher education: learning from \& with each other. In Boud, D., Cohen, R., \& Sampson, J. (Eds.) Routledge Taylor \& Francis Group. New York: USA.

Bertucci, A., Conte, S., Johnson, D. W. \& Johnson, R. T. (2010). The impact of size on cooperative group on achievement, social support and self esteem. The Journal of General Psychology. 137 (3), 256272.

Blazer, C. (2008). Extended school days. Information capsule research services (vol. 0705). Retrieved from http://drs.dadeschools. net/Information Capsules/IC0705.pdf on June 28, 2015.

Budhiraja, S. \& Sareen, S. (2013). Effect of anxiety and study habits on the academic achievement of senior secondary school students. International Multidisciplinary Journal of Applied Research.1(5). 93-94.

Cerna, M.A. \&Pavliushchenko, K. (2015). Influence of study habits on academic performance of international college students in shanghai. Higher Education Studies. 5 (4), 42-55.

Ebele, U. F. and Olofu, P. A. (2017). Study habit and its impact on secondary school students' academic performance in biology in the Federal Capital Territory, Abuja. Educational Research and Reviews. 12(10), 583-588.

Ehsan, T. (2017). Study habits as a function of academic achievement at university level. Unpublished Ph.D thesis at Allama Iqbal Open University Islamabad.

Elangovan, S. (2014). The proceedings of international conference on cloud computing and eGovernance: ICCCEG 2014 (4). Association of Scientists, Developers and Faculties. 
Fereidouni Moghadam, M., \& Cheraghian, B. (2009).Study habits and their relationship with academic performance among students of abadan school of nursing. Studies in Development of Medical Education. 6(1). 21-28.

Flippo, R., \&Caverly, D. (2000). Handbook of college reading and study strategy research. Mahwah, New Jersey: Lawrence Erlbaum Association Publishers.

Garner-O'Neale, L.D. \& Harrison, S. (2013). An investigation of the learning styles and study habits of chemistry undergraduates in barbados and their effect as predictors of academic achievement in chemical group theory Journal of Educational and Social Research. $3(2)$.

Goel, U. (2014). Comparative study of study habits in relation to academic achievement of senior secondary school students. Gyanodaya. 7(2).

Hall, M., Ramsay, A. \& Raven, J. (2004). Changing the learning environment to promote deep learning approaches in first year accounting students. Accounting Education: An International Journal, 13(4), 489-505. ISSN 1468-4489 DOI: $10.1080 / 0963928042000306837$.

Harrop, D., \& Turpin, B. (2013). A study exploring learners' informal learning space behaviors, attitudes, and preferences. New Review of Academic Librarianship, 19(1), 58-77.

Helsel, D. G. \& Miles, R. J. (1985). Assessment of student study habit effects on academic performance in introductory agronomy courses. Journal of Agronomic Education. 14 (2).

Holt, J. S. (2007). Study habits for lifetime. Retrieved from http://www.spidersburn.com/smart section.Item.14/ study habits 4-4 lifetime, html.

Hong, E., \& Milgram, R. M. (2000). Homework: motivation and learning preference. Westport, Connecticut: Bergin Garvey. 
Hu, H. \& Du, Z. (2012). We based inquiry of autonomy in foreign language learning as aenglish major in higher vocational college. Retrieved from:

https://books.google.com.pk/books?id=jiwCDT3QuvUC\&pg $=P A 45 \& d$ $q=$ self + directed + study + habits \&hl $=e n \& s a=X \& v e d=0 a h U K E w j s-$ IuYkZXVAhUDwxQKHZQTDY0Q6AEIPDAF\#v=onepage\&q=self\% 20directed\%20study\%20habits\&f=false. on: July 16, 2017.

Igun, S. E., \&Adogbeji, O. B. (2007). Study habits of postgraduate students in selected Nigerian universities. Library Philosophy and Practice (e-journal). 153. Retrieved from: http://digitalcommons.unl.edu/libphilprac/153/on June 3, 2017.

Jones, C. H., Slate, J. R. and Kyle, A. (1992), Study skills of teacher education students. Teacher Education, 28 (1), 7-15.

Kumar, S. (2015). Study Habits of undergraduate students. International Journal of Education and Information Studies. 5 (1), 17-24.

Kuther, T. L. (2015). The psychology major's handbook (4th ed.). Cengage Learning. Boston: USA.

Lawrence, A. S. A. (2014). Relationship between Study habits and academic achievement of higher secondary school students. Indian Journal of Applied Research. 4(6), 143-145.

Lexico by Oxford Dictionary (2019). Study. Retrieved from: https://www.lexico.com/en?search_filter=dictionary. Retrieved on: September 21, 2019

Leyden, A. (March 20, 2015). 10 good habits for students: how top students learn. Retrieved from: https://www.goconqr.com/en/examtime/blog/good-habits-forstudents/ on July12 2019,

Macpherson, A. (2015) Cooperative learning group activities for college courses. Surrey, British Columbia, Canada: Kwantlen Polytechnic University.

Mark, A., \& Howard, C. (2009). How to study. Psychological Science, 20(4), 516-522. 
Nonis, S. A. \& Hudson, G. I. (2010). Performance of college students: impact of study time and study habits. Journal of Education for Business. 85(4), 229-238, DOI: 10.1080/08832320903449550.

Odiri, O. (2015). Relationship of study habits with mathematics achievement. Journal of Education and Practice. ISSN 2222-1735 (Paper) ISSN 2222-288X (Online) 6(10). Retrieved from: https://files.eric.ed.gov/fulltext/EJ1081665.pdfon: June 12, 2018

Patel, B. V. (1976), Study habits inventory. In D.M.Pestonjee, (Ed.) Second handbook of psychology and social instruments. Concept Publishing Company, New Delhi.

Patel, G. (2016). An achievement motivation and study habits of school going students. Redshine International press, Lunawada: India

Rabia, M., Mubarak, N., Tallat, H., \& Nasir, W. (2017). A study on study habits and academic performance of students. Retrieved from: https://www.researchgate.net/publication/322206720on: September 22, 2019.

Rinsema, R. M. (2016). Listening in action: teaching music in the digital age. Taylor \& Francis. New York.

Nonis, S. A. \& Hudson, G. I. (2006). Academic performance of college students: influence of time spent studying and working. Journal of Education for Business. 81(3), 151-159, DOI: 10.3200/ JOEB. 81.3.151-159

Stinebrickner, Todd R. and Ralph Stinebrickner (2004). Time-use and college outcomes. Journal of Econometrics. 121(1-2), 243-269.

Tait, P. (2016). The importance of great teaching on children's success. Retrieved from: https://www.telegraph.co.uk/education/educationopinion/12201014/ The-importance-of-great-teaching-on-childrens-success.html on: March 12, 2017.

Walton, G. (2006). Learners' demands and expectations for space in a university library: outcomes from a survey at loughborough university. New Review of Academic Librarianship. 12(2), 133-149, DOI: 10.1080/13614530701330430. 
Willingham, D. T. (2010). Have technology and multitasking rewired how students learn?, ask the cognitive scientist. American Educator(Summer): 23-28.

Yu, D. D. (2011). How much do study habits, skills, and attitudes affect student performance in introductory college accounting courses?.New Horizons in Education. 59(3), 1-15.

\section{Citation of this Article:}

Ehsan, T., \& Sultana, N. (2020). Predicting the role of study habits in academic achievement; A study of university students in Punjab.

Pakistan Journal of Education, 37 (1), 95-112. 